\title{
Politiske skandaler i danske medier 1980-2010
}

Mark Blach-Ørsten lektor, CBIT Communication, Business and Information Technologies, Roskilde Universitet

Artiklen søger at afdække den historiske udvikling af politiske skandaler i Danmark fra 1980 til 2010. Der skelnes mellem to typer af politiske skandaler. Politikskandaler, det vil sige skandaler, der udspringer af en ministers eller politikers politiske arbejde, eller normskandaler, der udspringer af en ministers eller politikers personlige handlinger, enten i rollen som politiker eller i rollen som privatperson. Når det gælder politikskandaler, konkluderer artiklen, at disse typisk rammer ministre og opstår inden for ressortområder, der er under pres, enten internt politisk eller fra forandringer i omverdenen. Dette gælder for eksempel Tamilsagen fra 1993 samt nyere skandaler som Lækagesagen (2010), Jægerbogssagen (2010) og Rønn-sagen fra i år. I forhold til normskandalerne konkluderer artiklen, at disse kan ramme både ministre og MF'ere og i stadig højere grad går tættere på politikernes privatliv. Samlet konkluderer artiklen, at politiske skandaler i danske medier er i vækst især fra år 2000 og fremefter, og at dette - med visse forbehold - kan betragtes som en fordel for demokratiet.

\section{Hvad er en skandale?}

Politiske skandaler er centrale for forståelsen af moderne demokrati. Ikke alene afspejler den medialiserede politiske skandale det stadig skiftende magtforhold mellem medier og politikere, skandalerne kan også ses som et brydningspunkt i det moderne samfunds overordnede udvikling med store konsekvenser for det offentlige liv og den offentlige debat (Thompson, 2000). Alligevel findes der intet overblik over den politiske skandales udvikling i Danmark. Skandaler har dog længe været allestedsnærværende i medierne, hvilket også afspejles i mængden af studier om politiske skandaler (Thompson, 2000; Tumber \& Waisbord, 2004; Esser \& Hartung, 2004; Schudson,
2004; Jacobsson \& Löfmarck, 2008; Allern \& Pollack, 2009; Juntunen \& Väliverronen, 2010). Skandaler ses i dag som en fast del af den politiske journalistik i lande så forskellige som USA, Tyskland, Sverige, Norge, Finland, Argentina, Japan, Indien og Sydkorea. Skønt ældre historie også er rig på medierede skandaler, så kædes den moderne politiske skandale ofte tæt sammen med udviklingen af den undersøgende journalistik med Watergateskandalen som det idealtypiske eksempel (Ørsten, 2009). Hos Molotoch \& Lester (1974) ses den politiske skandale som journalistikkens højdepunkt, det øjeblik, hvor journalistikken for alvor lever op til rollen som den fjerde statsmagt. Markovits \& Silverstein (1988) tager dette argument skridtet videre og hævder, at politiske skandaler kun kan finde sted i demokratiske samfund, fordi netop demokratiske samfund anerkender behovet for at stille politikere til ansvar over for deres vælgere. Eksistensen af politiske skandaler er således med til at adskille åbne, demokratiske samfund med en fri presse fra diktaturer.

Tumber \& Waisbord (2004) mener imidlertid, at skandalerne i dagens mediebillede langt fra drives alene af demokratiske idealer og undersøgende journalistik. I stedet fremhæver de, at det er tabloidmedierne, som i dag er hoveddrivkraften bag skandaler, og at baggrunden for denne skandalefiksering hovedsageligt er økonomisk (Ørsten, 2009). Thumber \& Waisbord anerkender på den ene side Watergate-skandalens betydning, men fremhæver på den anden side, at moderne, økonomisk trængte medier ikke har råd til at investere i langsom, grundig undersøgende journalistik. Den politiske skandale er i stedet blevet overtaget af tabloidmedierne og ikke mindst det umættelige 24/7 nyhedskrav fra internettet og tv's nyhedskanaler. For disse medier er skandaler, især skandaler med en stærk personfiksering, en nem, billig og succesfuld måde at tilfredsstille kravet om konstante nyheder. "As a consequence, the floodgates of scandal news have been opened, making it possible to disseminate gossip, innuendo, and other scandalous fare." (Thumber \& Waisbord, 2004: 1147). 
Thompson $(2000,2004)$ derimod anlægger et perspektiv, der går på tværs af både økonomi og journalistik. Når skandaler er blevet et fremtrædende træk ved det offentlige liv i det senmoderne samfund, skyldes det medialiseringen af samfundet, som den stadige udbredelse af informations- og kommunikationsmedier - særligt nyhedsmedier - har medført. Medialisering betegner ifølge Hjarvard (2008: 28) "Den proces, hvor samfundet i stigende grad underlægges eller bliver afhængigt af medierne og deres logik." Hjarvard (2008) fremhæver ligeledes, at medialisering ikke er en universel proces, der gælder alle samfund, men at der først og fremmest er tale om en udvikling, som har fundet sted inden for vestlige samfund fra den sidste del af det tyvende århundrede og fremefter. Hos Thompson betegner medialisering en lignende proces, hvorved det hovedsageligt er via medierne, at vi som borgere i det senmoderne samfund orienterer os om politik, kultur, økonomi, underholdning osv. Thompson ser således den politiske skandale som en del af de overordnede sociale og strukturelle forandringer, som medialiseringen er med til at skabe. Centralt i disse forandringer står udviklingen af informations- og kommunikationsmedierne. "Skandalen er først og fremmest blevet et så fremspringende træk ved det offentlige liv i det moderne samfund, fordi de personer (og institutioner), der færdes i den offentlige arena, er meget mere synlige, end de nogensinde har været før i tiden, og fordi deres mulighed for at trække en grænse mellem deres offentlige image og deres privatliv er meget mere begrænset. I denne moderne tid med medieret synlighed er skandalen en konstant trussel for de mennesker (og institutioner), hvis liv er kommet i offentlighedens søgelys." (Thompson 2000: 18).

\section{Tabloidsering og personalisering}

Diskussionen om skandalens fremvækst og dens årsager trækker, som det fremgår af ovenstående, tråde til andre generelle diskussioner om udviklingen inden for henholdsvis medier og politik. Hvad angår medieudviklingen, rækker debatten om tabloidsering, som Thumber \& Waisbord (2004), lægger sig i forlængelse af i deres kritik af skandaler, tilbage til begyndelsen af 1990'erne (Esser, 1999; Louw, 2005). Tabloidsering er et omstridt begreb (se Esser, 1999), men betegner i denne sammenhæng den proces, hvorigennem nyhedsdækningen i morgenaviser, tv-aviser og netaviser i stigende grad, og styret af økonomiske incitamenter, forandrer sig i retning af formiddagsbladenes nyhedsdækning. Denne udvikling betegnes internationalt som en nedgradering af 'hard news' - det vil sige politiske og økonomiske nyhedshistorier - og en opgradering af 'soft news' - hvor nyheder i klassisk forstand er erstattet med gossip og underholdning, og po- litiske historier i stigende grad handler om politikernes privatliv og/eller skandaler (Esser, 1999, Sparks \& Tulloch, 2000; Louw 2005).

Studier af tabloidsering fremhæver store forskelle mellem udviklingen i forskellige lande, ligesom tabloidsering heller ikke forstås som noget entydigt negativt, da det tabloide stof, for eksempel fokusering på politikernes privatliv, også kan siges at engagere nye læsergrupper, der ikke tidligere har vist interesse for politik (Esser, 1999; Sparks \& Tulloch, 2000). I Danmark viser analyser af den politiske journalistik på den ene side, at 'hard news' stadig ligger højt på dagsordenen i form af nyhedshistorier med fokus på politik (Blach-Ørsten \& Bro, 2009), mens andre analyser peger på, at politikere, der er gode til at skabe konflikt, drama og sensation, har lettere ved at komme til orde i medierne og dermed sætte dagsordenen (Esmark \& Blach-Ørsten, 2011). Et case-studie af mediernes dækning af Farum-sagen (Carstensen, 2005) finder imidlertid ikke empirisk støtte for en generel tabloidsering af danske aviser.

Når det drejer sig om udviklingen af politik, ligger Thompsons syn på det offentlige liv, og især på ophævelsen af skellet mellem offentligt image og privatliv, på linje med debatten om personalisering af politik (Louw, 2004; Rahat \& Sheafer, 2007; Karvonen, 2007, 2010). Karvonen (2007: 2) beskriver personalisering som en tese om, at enkelte politiske aktører (især partiledere) spiller en stadig mere dominerende rolle i den politiske debat/dækning, og at dette sker på bekostning af et fokus på politiske partier som kollektive aktører. Der er især to årsager til denne personalisering. Den ene peger på, at udviklingen er et udtryk for en generel individualiseringstendens i vestlige samfund. Den anden årsag, som Karvonen (2007) fremhæver, er tv's dominans i den politiske kommunikation og det deraf følgende fokus på personer og performance. Andersen \& Borre (2005) fremhæver således også, på baggrund af et studie af de senere danske folketingsvalg, at tv's fokusering på partilederne har en effekt på vælgernes bedømmelse og stemmeafgivning, hvorfor at netop ledernes personlige stil og fremtræden på tv kan have betydning i en valgkamp.

En tredje årsag til personalisering kan dog findes inden for de politiske institutioner selv, særligt partiinstitutionen. Her har en professionalisering af den politiske kommunikation med særligt fokus på topkandidaterne fundet sted siden begyndelsen af firserne, ligesom en mere virksomhedspræget topstyring har vundet indpas også på dagligt niveau i de forskellige politiske partier. Denne institutionelle personalisering (Rahat \& Shesafer, 2007) ses ofte som en tilpasning til mediernes logik, men dette skal dog ikke forstås som en undertvingelse af en tidligere og renere politisk logik (Esmark \& Blach-Ørsten, 2011). 
Snarere kan en succesfuld 'overtagelse' af medielogikker give politikere og deres institutioner en del af den magt over mediedagsordenen tilbage, som de tabte ved partipressens afvikling.

Karvonen $(2007,2010)$ er generelt kritisk over for tesen om personalisering og fremhæver, at der kun er få studier, som entydigt har bekræftet tesen empirisk. Men Karvonens gennemgang af studier omkring personalisering medtager ikke de mange studier af politiske skandaler. I stedet er fokus på generelle studier af politik og på studier af valgkampe. At skandaler, som jo af natur er persondrevne, ser ud til at være stigende i antal i en lang række lande fra 1980'erne og fremefter, kunne derfor ses som et yderligere argument for personaliseringstesen (Thumber \& Waisbord, 2004).

\section{Synd eller magtkamp?}

Ser man på den specifikke tilgang til analyser af politiske skandaler, er der især to klare skillelinjer mellem de hidtidige studier. De analyser, der i overvejende grad begriber skandaler som normbrud - et moderne syndsforladelsesritual, "hvor et samfund konfronterer sine medlemmers fejl og overtrædelser, og ved at gennemgå den nogle gange smertefulde proces af afsløring, fordømmelse og gengældelse i den sidste ende bekræfter de normer, konventioner og institutioner, der udgør samfundsordenen.” Thompson (2000: 243). Denne tilgang tager udgangspunkt hos Durkheim (Thompson, 2000; Jacobsson \& Löfmarck, 2008) og anskuer skandaler som et udtryk for en overskridelse af samfundets fælles normer, hvad enten disse normer så er erkendte eller skjulte. Når normen brydes, afsløres normen samtidig som værende eksisterende, som værende en del af samfundets fælles normsystem (Jacobsson \& Löfmarck, 2008). Disse normer kan være normer og regler for god opførsel i det offentlige rum, men de kan også rumme mere idealiserede forestillinger om for eksempel bestemte personers optræden. I dette lys ses skandaler som ritualer, der har til hensigt at påminde samfundet om de fælles normer og idealer, samfundet er bygget op omkring, eller har til hensigt at diskutere disse normer for i den sidste ende at tage afstand fra en norm og samtidig derved at indføre en ny norm. Eller som Thompson (2000: 243) konkluderer om dette teoretiske syn på skandaler: "I vores moderne medierede verden er skandalen den verdslige udgave af synd."

En anden tilgang til analysen af skandaler er at betragte skandaler som "en kamp om symbolsk magt med omdømme og tillid som indsats." (Thompson, 2000: 253). Offentlighedens søgelys, medierne, giver i Thompsons forståelse adgang til den symbolske magt, der beskrives som den måske mest dominerende magtform i det medierede samfund. Med symbolsk magt forstås kampen om omdømme, prestige, tillid og anseelse. En magtkamp, som Thompson betegner som en at de væsentligste i det senmoderne samfund, og en magtkamp, som næsten udelukkende finder sted med medierne som kamparena. Symbolsk magt opbygges via medierne, men trues af selv samme medier i form af den medialiserede skandale.

Tidligere analyser af politiske skandaler i Norge og Sverige viser, at skandalerne ofte omhandler lovbrud eller brud på samfundets normer og regler. Disse norm- og lovbrud gælder dog ofte bemærkelsesværdige små overtrædelser, såsom manglende licensbetaling eller det faktum, at man har betalt for sort arbejde. Jacobsson \& Löfmarck (2008) og Allern \& Pollack (2009) forklarer den særlige skandinaviske tendens med, at forskellige politiske kulturer har forskellige normer, og dermed grænser, for normbrud. En analyse af norsk identitet og selvopfattelse fremhæver, at nordmænd er nøjsomme, moraliserende (næsten puritanske) og præget af velfærdsstatens lighedsideologi (Eriksen, 1993). Allern \& Pollack (2009) fremhæver desuden, at den omfattende lovregulering, som præger de skandinaviske velfærdsstater har skabt en grobund for en særlig type af skandinavisk politisk skandale, hvor den politiske 'synd' er, at politikeren ikke selv lever op til velfærdstatens lighedsideologi og fællesskabsnormer, herunder den strenge detailregulering. Set i dette lys virker det derfor som en væsentlig pointe i en analyse af politiske skandaler i Danmark, at tage højde for, at der netop må findes to overordnede typer af politiske skandaler: Politikskandalen og normskandalen. Denne opdeling tager udgangspunkt i inden for hvilken sfære, den politiske (offentlige) eller den private, som den normoverskridelse, der leder til skandalen, finder sted.

Fælles for begge typer af skandaler er, at de handler om ære, tillid og omdømme, men at udgangspunktet for skandalen, politikskandale eller normskandale, også opstiller forskellige forudsætninger for den kamp, som skandaler er udtryk for. En politikskandale vil således i udgangspunktet kunne lede til anklager om decideret lovbrud i forhold til ministeransvarlighedsloven, mens et normbrud ikke i udgangspunktet behøver at involvere et lovbrud, hvorfor konsekvenserne af normskandaler i udgangspunktet er mindre alvorlige end konsekvenserne af en politikskandale. En normskandale kan dog involvere brud på andre love end ministeransvarlighedsloven, såsom straffeloven, færdselsloven osv.

Denne opdeling af skandaletyper minder om den brede definition af politiske skandaler, som også Esser og Hartung (2004: 1041) anvender: "We define scandal as the intense public communication about a real or imagined defect that is by consensus condemned, and that meets universal indignation or outrage." Dette betyder, at kernen i en skandale er en overskridelse el- 
ler overtrædelse af love, normer, værdier eller regler, og skandaler kan derfor overordnet set betragtes som en del af den diskursive kamp om grænserne for samfundets etik og moral (Ørsten, 2009). Thompson (2000: 25-26) peger på følgende egenskaber som særligt karakteristiske for den politiske skandale: 1) Skandalen indebærer en overtrædelse af værdier, normer eller moralregler. 2) Den indeholder et element af fortielse eller hemmeligholdelse. 3) Udenforstående misbilliger overtrædelse og hemmeligholdelsen. 4) Misbilligelsen kommer til offentligt udtryk og deles af flere aktører, der giver udtryk for dette. 5) Afsløringen af skandalen kan bidrage til at skade de involveredes politiske status og position, men det behøver ikke at være tilfældet.

\section{To typer af politiske skandaler}

Thompson (2000) opstiller tre typer af skandaler: Politiske sexskandaler, økonomiske politiske skandaler og magtskandaler, den sidste type af skandaler har dog også flere undertyper af skandaler. Thumber (2004) opstiller ligeledes tre typer af skandaler. Allern \& Pollack (2009) opererer derimod med kun to typer af skandaler: politikskandaler og politikerskandaler, hvor politikskandaler beskriver skandaler, der kan knyttes til offentlig politik, mens politikerskandaler beskriver skandaler, der kan knyttes til politikernes privatliv. Analysen af politiske skandaler i Danmark lægger sig i forlængelse af Allern \& Pollack (2009) ved kun at skelne mellem to overordnede typer af politiske skandaler. I denne sammenhæng foreslås dog betegnelsen 'normskandale', der skal ses som en teoretisk præcisering af begrebet politikerskandale med særligt fokus på, hvorfor normer og normbrud kan forstås som andet og mere end personsager, jf. Jacobsson \& Löfmarck (2008).

1. Politikskandaler, det vil sige skandaler, der udspringer af en ministers eller politikers politiske arbejde. Politikskandaler drives frem af den undersøgende journalistik og afspejler på denne måde tanken hos Molotoch \& Lester (1974) om den politiske skandale som et højdepunkt for pressen i rollen som fjerde statsmagt. Politikskandaler betragtes på grund af deres fokus på den politiske substans som 'hard news'.

2. Normskandaler, der udspringer af en ministers eller politikers personlige handlinger, enten i rollen som politiker eller i rollen som privatperson. Normskandaler drives frem af den tabloide udvikling i medierne, men kan også siges at spejle udviklingen/stabiliteten i samfundets overordnede norm og moralkodeks (Thompson, 2000; Jacobsson \& Löfmarck, 2010). Normskandaler betragtes på grund af deres fokus på politikeres privatliv som 'soft news'.
Som hos Thompson skal de to skandaletyper ses som idealtypiske i den weberianske tradition. Det vil sige, at de fremhæver bestemte træk ved den politiske skandale og derved tillægger andre træk mindre betydning. Det skal også fremhæves, som hos Thompson, at der kan være en glidende overgang mellem den ene og anden type af skandale, ligesom en skandale kan begynde sit liv som en type af skandale og ende som en anden (jf. Ørsten, 2009). Et eksempel på en skandale, der befinder sig i grænselandet mellem de to typer, er Rushdie-sagen (1996), der omhandler justitsminister Bjørn Westh og statsminister Poul Nyrup Rasmussen. Begge anklages for at træffe en forkert, men ikke ulovlig beslutning om at rykke/aflyse forfatteren Salman Rushdies besøg til København for at modtage en litteraturpris. Beslutningen om at rykke/ aflyse Rushdies besøg er ikke ulovlig, og skønt dele af debatten handler om justitsministeren og dennes handlinger som minister med ansvar for at aflyse/rykke mødet, så handler skandalen især om dårlig kommunikation og statsministerens indblanding, og om hvorvidt og hvordan Danmark taber ansigt i udlandet ved at aflyse besøget. Sagen udvikler sig således til en debat om statsministerens lederevner, og hans 'synd' er først og fremmest, at Danmark taber ansigt i udlandet. Af disse årsager er skandalen i den nedenstående gennemgang kategoriseret som en normskandale.

\section{Metode}

Denne artikel udspringer af et nordisk forskningsprojekt om politiske skandaler (Allern \& Pollack (red), 2011). Dette projekt har til formål at skaffe et systematisk overblik over politiske skandaler i Danmark, Finland, Norge og Sverige. Denne artikel fokuserer udelukkende på danske skandaler fra 1980 til 2010. Ligeledes fokuserer den udelukkende på skandaler, som involverer politikere i Folketinget. Der findes i Danmark ikke mange politiske skandaler, der involverer for eksempel kommunale politikere, der har sat deres aftryk på den nationale mediedagsorden. Undtagelsen er korruptionssagen fra Aalborg fra $1981 \mathrm{og}$ Britxtoftesagen fra 2002. I den nordiske analyse blev skandaler, der inddrog fagbevægelsen, også analyseret. I Danmark gælder det to sager: Sagen om Dansk Folkeferie (1987) og Willy Strube-sagen (2001). Af plads og fokushensyn er disse, ligesom de kommunale skandaler, ikke medtaget i denne artikel. Barker (1994) gennemgår 146 skandaler fra tyve demokratiske lande og konkluderer, at der er store vanskeligheder ved og meget forskellige traditioner for, hvordan man definerer en begivenhed som en 'skandale', og forskning i skandaler er derfor i udgangspunktet udfordret af problemer med at definere sit problemfelt. Det gælder også dette projekt. Udvælgelsen af politiske skandaler i både denne artikel 
og det fælles nordiske projekt er derfor sket på baggrund af en lang række kilder. Først og fremmest har søgninger i forskellige artikeldatabaser (i Danmark Infomedia) dannet baggrund for en oversigt over mulige skandaler. Derudover er der suppleret med oplysninger fra historiebøger, politiske årbøger, leksika samt interview med politiske journalister. I udgangspunktet har fokus i det nordiske forskningsprojekt været på større politiske skandaler, forstået som skandaler, der har været højt prioriteret over længere tid i mere end et medie. Denne tilgang gør, at de udvalgte skandaler i denne artikel ikke nødvendigvis skal ses som en udtømmende liste over samtlige politiske skandaler i Danmark i den undersøgte periode. For eksempel er to, efter de anvendte kriterier mindre politiske skandaler, ikke med. Dette gælder socialdemokraten Jacob Bukstis fartoverskridelse (2003) og SF'eren Kamal Qureshis to sager fra 2008 om henholdsvis brug af falskt navn og eksamenssnyd. For yderligere gennemgang af metoden bag det fælles nordiske projekt om politiske skandaler henvises til Allern, Kantola, Pollack \& BlachØrsten (2011).

\section{Politiske skandaler i Danmark 1980-2010}

Analysen af politiske skandaler tager udgangspunkt i 1980, da forskningen i politisk journalistik i såvel Danmark som resten af Skandinavien peger på, at det var fra omkring 1980'erne og fremefter, at den politiske journalistik løsrev sig afgørende fra sit partipolitiske udgangspunkt og blev selvstændiggjort som politisk institution, kaldet nyhedsinstitutionen (Lund, 2002, Ørsten, 2004, 2005; Allern \& Blach-Ørsten, 2011). Et kort blik i mediehistorien i Danmark fortæller, at de to tabloidaviser, Ekstra Bladet og B.T., havde en tredje storhedstid fra midten af tresserne og op gennem 1970'erne (Jensen (red), 1997). Særligt Ekstra Bladet slog igennem med skandalejournalistik, der satte magtfulde personer på forsiden. Det var også Ekstra Bladet, der i 1978 stod bag Danmarks første store medierede politiske skandale, nemlig 'afsløringen' af Ritt Bjerregaards hotelregning fra hotel Ritz i Paris. En skandale, der førte til Ritt Bjerregaards fyring som undervisningsminister.

Fra 1980'erne og fremefter har tv-mediet haft en stadig mere dominerende rolle i den politiske kommunikation, og selv i senere undersøgelser af danskernes medievaner ligger tv i top med netaviserne på andenpladsen (Schrøder, 2009). Dette skyldes uden tvivl også, at tv nu sender nyheder 24/7 og dermed i endnu højere grad end tidligere dominerer nyhedsudbuddet. Men skønt tv således dominerer hos forbrugerne af nyheder, viser analyser af nyhedsmediernes fødekæde (Lund, Willig \& BlachØrsten, 2009), at langt størstedelen af tv-nyhedernes historier har deres udgangspunkt i dagspressen. Mange af

Tabel 1: Politikskandaler 1980-2010

\begin{tabular}{|c|c|c|}
\hline Årstal & Politiker & Skandale \\
\hline 1981 & Jens Risgaard Knudsen, trafikminister & Postskandalen \\
\hline 1983 & Svend Auken (S), tidligere arbejdsminister & Dagpengesagen \\
\hline 1984 & Niels Anker Kofoed, landbrugsminister & Kalø Gods Vildtforvaltning \\
\hline 1985 & Tom Høyem, grønlandsminister & Sagen om Kryolitselskabet \\
\hline 1986 & Britta Schall Holberg, indenrigsminister & Blødersagen \\
\hline 1992 & Anders Fogh Rasmussen, skatteminister & Kreativ bogføring \\
\hline 1993 & Erik Ninn Hansen, justitsminister & Tamilsagen \\
\hline 1994 & Ole Stavad, skatteminister & Sparnordsagen \\
\hline 2000 & Sonja Mikkelsen, trafikminister & Combussagen \\
\hline 2001 & Flemming Hansen, trafikminister & Udliciteringssagen \\
\hline 2003 & Hans Christian Schmidt, miljøminister & Miljøstøttesagen \\
\hline 2004 & Svend Erik Hovmand, skatteminister & TDC-sagen \\
\hline 2004 & Tove Fergo, kirkeminister & $\emptyset$ konomisk rod \\
\hline 2004 & Svend Aage Jensby, forsvarsminister & Lækage fra Folketingets kontroludvalg \\
\hline 2006 & Lars Barfod, fødevareminister & Kødskandalen \\
\hline 2007 & Anders Fogh Rasmussen, statsminister & Den hemmelige krig \\
\hline 2009 & Søren Gade, forsvarsminister & Jægerbogen/lækagesagen \\
\hline 2010 & Lars Løkke Rasmussen, statsminister & Overbetalingssagen/mailgate \\
\hline
\end{tabular}


de senere års skandaler er da også alle startet i dagspressen, fx Helle Thorning Schmidts skattesag, som B.T. var først til at sætte på dagsordenen, eller Lars Løkkes bilagssag, som Ekstra Bladet stod bag. Nicheaviser har dog også spillet deres rolle i skandalesagerne. Således startede dækningen og afsløringen af Tamilsagen i henholdsvis Dagbladet Arbejderen og Weekendavisen, mens Rønnsagen fra i år kom fra Informations forsider.

\section{Den politiske skandale 1 - Politikskandaler}

Tabel 1 viser, at der i den undersøgte periode er i alt 18 politikskandaler. Politikskandaler rammer i den undersøgte periode udelukkende siddende eller tidligere ministre og udspringer af en kritik af ministerens embedsførelse.

I flere tilfælde udspringer kritikken fra en dommerundersøgelse eller lignende. Dette gælder blandt andet 'Postskandalen' (1982/85), der handlede om store bevillingsoverskridelser hos Post- og Telegrafvæsnet, 'Dagpengesagen' (1983/85), der også omhandlede bevillingsoverskridelser, sagen om statens salg af aktier i Kryolitselskabet (1986) og Tamil-sagen (1990/1995), der omhandlede syltningen af tamilers lovmæssige krav om familiesammenføring (for en oversigt se Christensen, 1996). Dommerundersøgelser fører dog ikke altid til kritik. I Blødersagen blev indenrigsminister Britta Schall Holberg frifundet for at have et ansvar for sagen. Uden undtagelse er Tamil-sagen den analyserede periodes største politikskandale. Skandalen førte som bekendt ikke kun til den ansvarlige ministers fald (Erik Ninn-Hansen), men også til hele Schlüter-regeringens afgang i januar 1993 som følge af Tamilrapporten. Set i et journalistisk perspektiv kan Tamil-sagen sidestilles med Watergateskandalen fra 1973, og derfor også ses som et højdepunkt for den politiske journalistik i Danmark.

Samlet set viser analysen, at politikskandaler har høje omkostninger for de involverede politikere. Ud over Ninn-Hansens og Schülter-regeringens spektakulære afgang tæller perioden flere eksempler på afgange i form af fyringer eller mere eller mindre frivillig afgang. Det gælder for eksempel Anders Fogh Rasmussens 'frivillige' afgang som skatteminister efter sagen om kreativ bogføring, Ole Stavads afgang som skatteminister som følge af sagen om Sparekassen Nordjylland samt flere andre. Omvendt viser analysen også, at det er muligt at 'overleve' som minister på trods af omfattende kritik. Dette gælder for eksempel kritikken af statsminister Anders Fogh Rasmussen, der rejste sig på baggrund af dokumentaren om 'Den hemmelige krig' (2007), eller kritikken af statsminister Lars Løkke Rasmussen i forbindelse med overbetalingssagen/mailgate (2010), der omhandlede prisen for ydelser på private hospitaler samt muligt politisk pres på de involverede embedsmænd.

Analysen viser også, at visse ministerier forekommer mere skandaleramte end andre. For eksempel udspringer hele tre skandaler fra Skatteministeriet, mens Trafikministeriet i perioden rammes af to skandaler, det samme antal som også rammer Forsvarsministeriet. Ser man på de skandaleramte ministerier $i$ et mere overordnet perspektiv, kan man med udgangspunkt i for eksempel Tamilsagen og Rønn-sagen fra i år, samt med udgangspunkt i de i alt tre skandaler, der relaterer sig til Danmarks krigsindsats i henholdsvis Irak og Afghanistan, også pege på den mulighed, at skandaler rammer de ressortområder, der på forskellig vis er afgørende for en regerings politik, og som samtidig repræsenterer områder, hvor de politiske spilleregler, også i omverdenen (EU/FN), er til debat og diskussion.

\section{Normskandaler}

Tabel 2 viser udviklingen af normskandaler fra 1980 til 2010. I alt tæller perioden 17 normskandaler. Det fremgår dog tydeligt af tabellen, at normskandaler først for alvor får deres gennembrud fra år 2000 og fremefter. Perioden fra 1980 til 1989 tæller således kun to norm-skandaler, mens der er fire i den efterfølgende periode fra 1990-1999. Af skandalerne i disse to første årtier af undersøgelsen er især Arne Melchiors afgang som trafikminister samt Pia Gjellerups afgang som justitsminister og Bente Junckers afgang som socialminister interessante. Arne Melchoirs bilagssag er interessant, da den minder om Ritt Bjerregaards tidligere bilagssag. Selv om Melchoir ikke anklages for dyre hotelregninger, anklages han for en generel lemfældig omgang med bilag. Og som det var tilfældet med Ritt Bjerregard, ender sagen med Melchoirs afgang som minister.

De to efterfølgende sager er interessante, fordi regeringsskiftet efter Tamilsagen bragte en socialdemokratisk regering til magten under ledelse af Poul Nyrup Rasmussen. Nyrup overtog således magten i Danmark efter den største politiske skandale nogensinde og erklærede også ved sin tiltrædelse, at 1990 'erne skulle være et moralens og anstændighedens årti (Christensen, 1996). Så meget desto mere dækning og gennemslagskraft fik det i medierne, da Nyrup først måtte skille sig af med sin justitsminister, Pia Gjellerup og sin socialminister, Bente Juncker. Interessant er det også, at begge ministre blev fældet for handlinger, der ikke umiddelbart havde forbindelse til deres rolle som minister. Pia Gjellerup mistede sit ministerium på baggrund af økonomisk rod i den socialdemokratiske kursusejendom Solhavegård, som hun havde været bestyrelsesformand for. Bente Juncker måtte forlade 
Tabel 2. Normskandaler $1980-2010^{2}$

\begin{tabular}{|l|l|l|}
\hline Årstal & Politiker & Skandale \\
\hline 1985 & Hans Engell, forsvarsminister & Sagen om 'hovsa-missilet' \\
\hline 1986 & Arne Melchoir, trafikminister & Bilagssag \\
\hline 1993 & Pia Gjellerup, justitsminister & Sagen om Solhavegård \\
\hline 1994 & Bente Jucker, socialminister & Sommerhussagen \\
\hline 1996 & Bjørn Westh, justitsminister \& Poul Nyrup Rasmussen, statsminister & Rushdie-sagen \\
\hline 1997 & Hans Engell, partiformand & Betonklodsen på Helsingørmotorvejen \\
\hline 2001 & Anita Bay Bundegaard, udviklingsminister & Tvivl om akademisk titel \\
\hline 2002 & Anders Møller, MF for Venstre & Sexchikane \\
\hline 2002 & Thor Pedersen, finansminister & Anklager om ulovlig hektar-støtte \\
\hline 2004 & Flemming Oppfeldt, MF for Venstre & Anklager om pædofili \\
\hline 2005 & Henriette Kjær, familie - og ligestillingsminister & Rod i privatøkonomien \\
\hline 2005 & Ulla Tørnæs, udviklingsminister & Anklager om sort arbejde i mandens virksomhed \\
\hline 2007 & Morten Messerchmidt, MF for Dansk Folkeparti & Anklager om nazihilsen i restaurant Grøften \\
\hline 2008 & Jeppe Kofoed, udenrigspolitisk-ordfører for Socialdemokratiet & Sexsagen \\
\hline 2008 & Lars Løkke Rasmussen, finansminister & Bilagssag \\
\hline 2010 & Lene Espersen, udenrigsminister & Feriesagen \\
\hline 2010 & Helle Thorning Schmidt, partiformand & Skattesagen \\
\hline
\end{tabular}

Socialministeriet på grund af en speget sag omkring sit sommerhus. Juncker havde klaget over gener ved, at otte handicappede var flyttet ind i et sommerhus ved siden af hendes, og fik senere også beskyldt den embedsmand, der havde behandlet (og afvist hendes klage) for seksuelt misbrug af de handicappede - hvilket var en lodret løgn.

Senere blev Nyrup selv involveret i Rushdie-sagen, hvor den danske regering på opdigtet baggrund afviste at modtage forfatteren Salman Rushdie, skønt det ellers var planlagt, at han skulle besøge København for at modtage en litteraturpris fra EU. Skandalen kostede ikke Nyrup statsministerjobbet, men forfulgte ham resten af hans tid som statsminister og var også med til at stemple ham som en dårlig kommunikatør (for en nærmere analyse af Rushdie-sagen, se Pedersen m.fl. 2000).

Fra år 2000 og fremefter sker der en klar vækst i antallet af normskandaler. Blandt andet indeholder perioden hele tre sexskandaler, nemlig Anders Møller-sagen, Flemming Oppfeldt-sagen og Jeppe Kofoed-sagen. Særligt disse sager kan antages at være udtryk for en større villighed hos medierne til at gå tættere på politikeres privatliv, da Danmark ikke tidligere, som det ellers er tilfældet i England og USA, har været plaget af sexskandaler. Politiske biografier af for eksempel Jens Otto Krag fortæller, at dette ikke skyldes, at der ikke har været potentielle sexskandaler at skrive om Snarere skyldes det, at medierne i 'gamle dage' valgte at respektere politikernes privatliv og skellet mellem politikeren som privat person og politikeren som offentligt person. Efter årtusindskiftet har dette skel været under pres, hvis ikke ligefrem opløsning - hvilket sexskandalerne kan ses som klare tegn på. Men i det hele taget søges politikere skandaliseret på nye måder via normskandalerne fra 2000 og fremefter. Ud over sexskandaler anklages ministre for misbrug af akademisk titel (Anita Bay Bundegaard), ulovlig hektarstøtte (Thor Pedersen), uorden i privatøkonomien (Henriette Kjær), sort arbejde (Ulla Tørnæs og (især) hendes mand), nazihilsner i Grøften i Tivoli (Morten Messerschmidt), at prioritere ferie fremfor arbejde (Lene Espersen) og skattespekulation (Helle Thorning Schmidt og hendes mand).

Modsat politikskandaler, der ofte bakkes op af undersøgelsesdomstole osv., er forløbene omkring diverse normskandaler langt mere rodet. Flemming Oppfeldt blev således anklaget for en række forhold, men kun $\mathrm{d} ø \mathrm{mt}$ for et enkelt, mindre betydeligt, forhold. Thor Pedersens hektarstøtte sag viste sig ved nærmere eftersyn heller ikke at kunne bære de store overskrifter, og Helle Thorning Schmidts stort opblæste skattesag endte med en klokkeklar frifindelse fra skattemyndighedernes side. Det fremstår med andre ord meget tydeligt, at disse sager i meget høj grad handler om mediernes italesættelse, ikke af faktiske overskridelser, men af mulige overskridelser af 
forskellige former for normer og etiske kodeks. Politikere i normskandaler er således ofte kun skyldige i mindre synder (hvis overhovedet), jf. Thompson (2000). Disse synder kan så diskuteres og forhandles i medierne, indtil en politiker kan opnå syndsforladelse og igen indtage sin plads som en respekteret repræsentant for befolkningen. Dette forløb betegner for eksempel Jeppe Kofoeds sexskandale, hvor han inden for kort tid måtte træde tilbage som udenrigspolitisk ordfører, sige undskyld til befolkningen, for så efter en fraværsperiode at vende tilbage til sin status som udenrigspolitisk ordfører for Socialdemokratiet. Også Henriette Kjær overlevede (i første omgang) sin turbulente privatøkonomi ved at træde tilbage som minister, for så senere at vende tilbage i den højt profilerede rolle som politisk ordfører. Lars Løkke Rasmussen overlevede en omfattende bilagsskandale (med undertoner af sexskandale) og blev alligevel statsminister, og Helle Thorning Schmidt indrømmede tidligt i forløbet af skattesagen, at hun havde begået nogle fejl, som hun undskyldte for, og var på den måde med til at 'sone' sine synder over for medierne og befolkningen allerede før skattemyndighederne frikendte hende. Omvendt var Lene Espersen meget lang tid om at undskylde, at hun valgte at tage på familieferie fremfor at deltage i et politisk møde med USA's udenrigsminister Hillary Clinton. En manglende en undskyldning, som senere blev fremhævet af medierne igen og igen.

\section{Diskussion}

Som det fremgår af tabel 3 nedenfor, sker der en stigning i antallet af politiske skandaler fra 1980 til 2010. Denne stigning sker dog først inden for det sidste årti, hvilket på mange måder svarer godt til den forandring af både politik og medier, som de forskellige studier af skandaler fremhæver som værende medvirkende årsager til væksten i antallet af politiske skandaler. For eksempel kan der ikke være tvivl om, at medielandskabet har forandret sig voldsomt fra år 2000 og fremefter, hvor øget konkurrence på alle platforme - papir, net, tv - har medført, at medierne i 2008 producerede mange flere historier end i 1998, uden at der var ansat tilsvarende flere journalister (Lund, Willig \& Blach-Ørsten, 2009).

Der er heller ingen tvivl om, at den øgede konkurrence har fremmet en mere tabloid journalistik både på nettet, på tv og i morgenaviserne, som kommer til udtryk i det øgede fokus på skandaler på tværs af medietyper. For eksempel var både Jeppe Kofoeds sexskandale og Helle Thornings skattesag på forsiden af såvel tabloidaviser som morgenaviser og nicheaviser, ligesom begge sager blev $\mathrm{d} x \mathrm{kket}$ intensivt på nettet, i tv-aviserne på begge kanaler og samt på TV News og DR-Update. Samme mønster gjorde sig gældende med Lars Løkke Rasmussens bilagssag og Lene Espersens feriesag samt de seneste sager fra indeværende år omkring Henriette Kjærs privatøkonomi og, efter at Information havde kørt sagen alene det første stykke tid, omkring Birte Rønn Hornbecks afgang som integrationsminister.

Tabel 3. Skandaletyper/årti.

\begin{tabular}{|l|c|c|c|}
\hline Skandaletype/Årti & Politikskandale & Normskandale & Skandaler i alt \\
\hline 1980-1989 & 5 & 2 & 7 \\
\hline 1990-1999 & 3 & 4 & 7 \\
\hline 2000-2010 & 10 & 11 & 21 \\
\hline Total & 18 & 17 & 35 \\
\hline
\end{tabular}

Omvendt kan de mange normskandaler ikke i udgangspunktet postuleres at give os et dårligere demokrati eller være udtryk for en fordummende journalistik (Sparks \& Tulloch, 2000). Dels kan skandalerne ses som en konsekvens af partiernes store fokus på partiledere og spidskandidater, samt partiernes større og mere professionelle promovering af disse topkandidater $\mathrm{i}$ alt fra talkshows til dokumentarprogrammer, aviskampagner og reality-tv. Dels kan de mange normskandaler ses som udtryk for, at velfærdssamfundet stadig har ideale forventninger til politikere, og at politikere, der svigter disse forventninger, samtidig bringer sig i konflikt med deres vælgere. Blandt disse forventninger kan siges at være, at politikere skal fremstå som værende på lige fod med vælgeren, hvilket kan forstås i lyset af velfærdsstatens ideologi om at stille alle borgere lige. Politikere bør således ikke være grådige (som Helle Thorning blev anklaget for), sløsede med deres midler (diverse bilagssager) eller dovne (Lene Espersens feriesag) - alle sammen egenskaber, der trækker i retning af de syv dødssynder og dermed understøtter tesen om skandaler som en moderne udgave af at synde.

Men når dette er sagt, står det også klart, at både medier og politikere konstant bør overveje graden af personalisering i både deres dækning og deres politiske kampagner, da flere eksempler fra de seneste ti år viser, hvordan store personsager - der set i bakspejlet viste sig slet ikke at være sager, eller kun i betydeligt mindre omfang end først antaget var normbrud - har præget mediernes dagsorden i uge- og månedsvis og derved - alt andet lige - berøvet andre og mere substantielle nyheder den opmærksomhed, som de efter det journalistiske væsentlighedskriterium burde have haft krav på.

Med ovenstående in mente skal det dog fremhæves, at politikskandalen, der jo i udgangspunktet omhandler den politiske substans, har vist, at medierne i Danmark 
lever op til Markovitz \& Silversteins (1998) demokratiske rolle som en fjerde statsmagt, der sikrer den fri debat ved at levere kritik af magthaverne. Medierne har således spillet en afgørende rolle i at synliggøre en lang række af kritisable forhold inden for en lang række forskellige ressortområder og siden været med til at stille ministre til ansvar for deres gerninger. Medierne har ikke udfyldt den rolle alene, men typisk i samspil med forskellige typer af undersøgelsesdomstole, kommissioner osv. Medierne har dog også alene været med til at afsløre stærkt kritisable forhold omkring for eksempel Tamilsagen, krigen i Afghanistan og Forsvarskommandoens lemfældige omgang med sandheden i forbindelse med Jægerbogssagen samt i Rønn-sagen fra indeværende år.

Samlet set må politiske skandaler betragtes som værende udtryk for et velfungerende demokrati, hvilket også tidligere har været fremhævet i forbindelse med studiet af skandaler, især i forhold til fraværet af politiske skandaler i lande med censureret eller på anden måde mindre fri presse (Markovits \& Silverstein, 1988; Thumber \& Waisbord, 2004). Omvendt kan skandaler også bruges af medierne til at promovere sig på, ligesom politikere kan forsøge at skandalisere deres modstandere/konkurrenter og således gøre skandalen til et politisk våben, der udelukkende tjener en politisk magtkamp (Allern \& Pollack, 2009).

Et overdrevet fokus på skandaler fra både politikere og mediers side kan lede til en tilstand af 'permanent skandalisering' (Thumber \& Waisbord, 2004), hvor alt eller det meste politik, kommer til at omhandle skandaler frem for andre politiske emner. Set i lyset af den klare vækst i politiske skandaler fra 2000 og fremefter kan det virke, som om Danmark har befundet sig i en tilstand af permanent skandalisering $i$ de sidste ti år. Og med de seneste skandaler fra $\mathrm{i}$ år, Henriette Kjær-sagen (II) og Birthe Rønn Hornbech-sagen, virker det ikke, som om denne udvikling står over for at ændre sig umiddelbart. Fremtidig forskning i politiske skandaler kunne derfor med fordel fokusere på, hvordan (hvis overhovedet) den permanente skandalisering påvirker vælgernes opfattelse af både politikere og politik.

\section{Litteratur}

Allern, S \& Pollack, E (2009) Skandalens markedsplass, Fagbokforlaget, Oslo.

Allern, S \& Pollack E (Eds.) (forthcomming): Political Scandal in the Scandinavian Countries, Nordicom, Göteborg.

Allern, S, Kantola, A, Pollack, E \& Blach-Ørsten, M (forthcoming) Nordic Political Scandals 1980-2010 in Political Scandal in the Scandinavian Countries, Nordicom, Göteborg.
Allern, S \& Blach-Ørsten, M (2011) The news media as a political institution, pp.92-105 in Journalism Studies, vol 12, No 1.

Blach-Ørsten, M \& Bro, P (2009) Den synkroniserede journalistik pp. 19-28 i Lund, Willig \& Blach-Ørsten (red.) Hvor kommer nyhederne fra, Ajour, Århus.

Carstensen, M. B (2005) Mediernes konstruktion af Farum-sagen, pp. 182.197 i Politica, 37 (2).

Christensen, J. P (1996) Skandalesager og embedsmandsansvar, pp 255 270 i Politica, bind 28 (3).

Eriksen, T.H (1993) Typisk Norsk, C. Huitfeldt forlag, Oslo.

Esser, F (1999) Tabloidization of News: A Comparative Analysis of Anglo-American and German Press Journalism pp. 291-324 in European Journal of Communication, vol 14 (3).

Esmark, A \& Blach-Ørsten, M (2011) Et komparativt blik på den politiske kommunikationskultur i Danmark pp. 3- 18 i Tidsskriftet Økonomi \& Politik, årgang 84, 1.

Esser, F, \& Hartung, U (2004) Nazis, Pollution, and no sex: Political Scandals as a Reflection of Political Culture in Germany pp.10401071 in America Behavioral Scientist, vol. 47.

Hjarvard, Stig (2008) En verden af medier, Samfundslitteratur, Frederiksberg.

Jacobsson, K \& Löfmarck, E (2008) A Socilology of Scandal and Moral Transgression: The Swedish 'Nannygate' Scandal pp.203-216 in Acta Sociologica, vol 51 (3).

Jensen, KB (red) (1997) Dansk Mediehistorie, Samlerens Forlag, København

Juntunen, L \& Väliverronen, E (2010) Politics of Sexting pp. 1-15 in Journalism Studies, IFirst Article, 2010.

Karvonen, L (2007) The Personalization of Politics, paper ECPR Conference, Pisa

Karvonen, L. (2010) The Personalization of Politics: A Study of Parliamentary Democracies ECPR Press, Colchester, UK.

Lund, AB, Willig, I. \& Blach-Ørsten, M (red.) (2009) Hvor kommer nyhederne fra? Ajour, Århus.

Louw, E. (2005) The Media and Political Process, Sage, London

Markovits, A.S. \& Silverstein, M (Eds.). (1998) The Politics of Scandal: Power and process in Liberal democracies, Holmes \& Meier, New York.

Merton, R. (1957) Manifest and latents functions, pp. 19-84 in R. Merton (Ed.) Social theory and social structure, Free Press, Glencoe IL.

Molotch, H \& Lester, M (1974) News as purposive behavior pp. 101-112 in American Sociological Review 3.

Pedersen, Ove K. \& Peter Kjær, Anders Esmark, Maja Horst, Erik Meier Carlsen (2000) Politisk Journalistik, CFJE, Århus.

Rahat, G \& Sheafer, T (2007) The Personlaization of Politics; Israel, 1949-2003, pp. 65-80 in Political Communication, 24.

Schudson, Michael (2004) Notes on Scandal and the Watergate Legacy pp. 1231-1238 in America Behavioral Scientist, vol. 47.

Sparks, C \& Tulloch J. (Eds.) (2000) Tabloid Tales, Rowman \& Littlefield, Oxford.

Thompson, John B (1995): Medierne og Moderniteten. Hans Reitzels forlag, København.

Thompson, John B (2000): Den politiske skandale. Hans Reitzels forlag, København.

Tumber, Howard (2004): Scandal and Media in the United Kingdom: From Major to Blair pp.1122-1137 in America Behavioral Scientist, vol. 47.

Tumber, H \& Waisbord, S,R (2004): Introduction: Political Scandals and Media Across Democracies, Volume 1, pp.1031-1039 in America Behavioral Scientist, vol. 47.

Ørsten, Mark (2004) Transnational politisk journalistik. Skriftserie for journalistik på RUC. 
Ørsten, Mark (2005) Nyhedsinstitutionen - et ny-institutionelt perspektiv på den medialiserede politiske kommunikation, pp. 13- $28 \mathrm{i}$ Økonomi \& Politik nr. vol. 78, nr 3.

Ørsten, Mark (2009) Den virksomhedspolitiske skandale, pp. 21- 38 i Langer, Kjær \& Horst (red.) Produktiv Journalistik, Handelshøjskolens Forlag, København.

\section{Noter}

1 Der gøres opmærksom på, at årstallet, der er tilknyttet de enkelte skandaler, kan diskuteres alt afhængigt af, om man taler om skandalens begyndelse, højdepunkt eller afslutning. Dagpengesagen, der 1985 bliver en sag for Svend Auken, relaterer sig til hans embedsperiode som arbejdsminister fra 1977 til 1982. Tamilsagen, der i 1993 leder til hele Schlüter-regeringens afgang, begyndte så tidligt som i 1987 og blev først afsluttet ved Rigsretten i 1995. Ligeledes gøres der opmærksom på, at de enkelte skandalers navn blot kan være et blandt flere navne, som gennem tiden er blevet anvendt til at beskrive skandalen.

2 Der tages de samme forbehold for årstal og navne som i note 1. 